\title{
VERSITA
}

10.2478/v10284-012-0011-1

\section{PATRIOTISM AND IMPERIALISM 1870-1914 EDUCATION \& THE YOUNG}

DAVID GANNON

"Propaganda aims to to turn resentment into rebellion or loose coalition into unity." (Mangan, 1986, p. 113)

Contemporary commentators and historians alike have commented on the way patriotic and imperial propaganda ' mushroomed' (Porter, 2004, p. 180) between 1870 and 1914. What is particularly remarked upon is the greater emphasis which was placed on patriotic and imperial themes in schools and youth groups. It is important then to examine this trend, to understand the reasoning and implementation so to be able to make a judgement as to its effectiveness and impact on the young of the day.

When examining the emphasis on patriotic and imperial themes in schools and youth groups it is first important to realize that it is a mistake to treat them as a homogenous whole. Treating Eton or Harrow the same as a school in a working class district of London or any larger industrial city would overlook some important differences in what propaganda was transmitted and how it was transmitted. As Mangan (1986, p. 113) points out, until 1902 there were essentially two different education systems, one encompassing the public schools and the other covering the vast majority of children. Only by accepting this fact can we begin to see clearly how and why values were transmitted and make some judgment as to its effect.

This difference can be seen clearly in the question of teaching materials for schools. A lot of focus has been on the introduction of new subjects in schools, especially the humanities, and the textbooks which were designed to teach these subjects. These text books, according to MacKenzie (1984, p. 177) were to instill a certain set of values; patriotism, good citizenship, and moral training. With a contemporary perception of external weakness and greater threat to Britain's position, it was natural to inspire the class of future leaders, through the example of role models who embodied virtuous and moral lives, to be part of the Imperial enterprise. 
However, there is a problem when this view is applied to the greater majority of school age children, those of working class families. Firstly, as Heathorn (1995, p. 398) notes, it is doubtful that working class schools could afford such textbooks and further doubtful that the upper classes wanted to share an equal partnership with them as well. As Porter (2004) comments:

What most Imperialists hoped was that the workers would be made proud to serve. (Porter, 2004, p. 206)

Rather than using the same textbooks as the elites, according to historians such as Heathorn (1995, p. 398), it is more enlightening to look at the readers which were made mandatory in the education codes from 1880. The readers were to help children "identify with the nation in the present, and be prepared to serve the nation in the future" (Yeandle, 2003). A very different message was being promoted than to the elites. Rather than one of leadership, it was promoting service to the nation, in essence, cementing the social stratification of society.

This was clearly a response to the contemporary view that since the enlargement of the franchise, traditional ties which had bound society together, was breaking down. New ties, the creation of social cohesion, had to be found. It was unlikely that the elites, as Porter (2004, p. 207) argues, would want to share "economic wealth, social status or political power" with the masses. The working classes would have to be made to feel included and valued in society, without giving them anything tangible.

Therefore, the readers stressed two main themes, a sense of racial inclusion and service to the larger group. By stressing the idea of ' Englishness' and belonging, the working classes could be proud of its hard won achievements. Moreover, by stressing that everyone was responsible for its maintenance, there was in Heathorn's words (Heathorn, 1995, p. 420) a clear "inference that social and political decisions would threaten the continued prosperity of the nation, empire and race."The working classes were to be proud of being English and content with the position in society they occupied.

Youth groups multiplied in the latter part of the nineteenth century and the beginning of the twentieth, they were used as another means of inculcating patriotic and imperial themes to youth. The Scouts, to some historians such as MacKenzie (1984, p. 246), were "consciously founded as agents of class conciliation, designed to inculcate evangelical values of temperance, self-discipline, obedience and piety." Involvement in these groups was seen as an opportunity to create a sense of pride in belonging to the English, pride also in serving the community, feelings which would be translated into a new social cohesion. Youth were to be proud to serve and be subordinate to the wishes and commands of the elites. Whether they were actively enthused or simply obeying was a matter dependent on their status in society. In essence, we can see the continuation of the stratification found in schools, the working classes were being offered, what Porter (2004, p. 168) has called, a "vicarious share in the broader national enterprise that had previously been appropriated by the upper classes alone", although it was not meant to be an equal one.

Some historians have argued that the effect of this increased emphasis on patriotic and imperial themes was translated into real and tangible results. Historians have argued that Mafeking night, popular enlistment for the Boer and First World Wars were the end result of this process.

A whole range of propagandist imperial bodies conventionally regarded as failure, in fact succeeded in diffusing their patriotic intentions and their worldview, if not the specific and sophisticated plans of action through almost every institution of British life (MacKenzie, 1984, p. 246). However, an examination of the mechanisms through which these feelings were to be transmitted, teachers and teaching, the youth groups, 
reveal that it is not as straightforward as some believe. A great deal of attention has been given to the new teaching methods which accompanied new classes and materials. As MacKenzie (1984) argues:

It was only through the new technique of teaching that history could achieve its proper purpose which was the inculcation of patriotism and good citizenship as well as the promotion of moral training. (MacKenzie, 1984, p. 177)

The interest of children was to be stimulated by exciting stories of the past, having everyday objects brought to class and shown their imperial significance, to make children ready for their patriotic duties. Furthermore, the invention of rituals and the involvement of school children and youth organizations was meant to foster the sense of being part of a larger enterprise. The habits of order and obedience formed by drill were seen, according to MacKenzie (1984, p. 228), as "inculcating industry, discipline" and "instilling habits of submission, order and neatness". In its entirety, as Heathorn (1995, p. 421) argues the effect was meant to transmit to youth the idea that loyalty to the nation superseded all other class and community loyalties. Blanch (1979) takes this further by arguing:

The evidence then suggests that a significant part of school time in the period 1880-1899 was spent in transmitting nationalistic and imperialistic values to children. Linked to the drill and discipline it would seem that the ethos was often militaristic and emotive. (Blanch, 1979 , p. 213)

As convincing as it sounds, there are some obvious problems with this reasoning. Firstly, doubtless though there were stimulating and exciting lessons, it is hard to accept that this was a universal experience. The evidence from working class memoirs, as argued by Porter (1984, p. 201), show that classroom imperial education was neither universal nor universally effective among the target audience.

Much of this could have been due to teachers. In elite schools there is a great deal of evidence of the dissemination of patriotic themes by teachers but even here, as Mangnan (1986, p. 118) concedes, it was not universal. In working class schools the situation makes it hard to support this argument. Teachers did not have prescribed curricula until early in the twentieth century as governments were afraid to alienate teachers or parents. Porter (1984, p. 202) therefore argues that what was taught was influenced by two pressures, the teachers and their attendant political leanings and agendas (often left wing and radical), and the pressure from parents who wanted their children's education to have practical application. Given these conditions, it is hard to agree that patriotic themes were as ubiquitous as some have argued.

Whilst the upper classes had sport to teach them esprit-de-corps, leadership, and manly prowess, the working classes had drill. Whilst perhaps effective in cultivating traits of order and obedience, it is hard to see how it was to give children a sense of patriotic pride. Through its encouragement in schools through the education acts of 1871 and 1875 and the view that it was described as an efficient teaching tool in pedagogical manuals, the effect may have been what Steadman-Jones (1974, p. 488) identifies as "deadening"rather than inspiring. It is perhaps more convincing to argue that the repetition of drill made it become seen as a chore or irritation rather than an exciting activity for the children leading to enthusiasm for empire.

As put forward by Mackenzie (1984, p. 246) working class children were to have received a "considerable infusion of middle-class values" whilst being members of youth groups. Drilling with weapons and association with the military may have stimulated some young people, but it must be remembered that some groups, especially those organised by the churches, were often wary of this connection. If this is the 
case, then the argument that notions of service to the nation and empire were being produced by these organisations, is not as convincing as previously thought. The common view of the dissemination of values through these groups also forgets the motivations of many for joining in the first place. A desire for sport, a release from the drudgery of daily life, a way to make friends were often behind the decision to join rather than patriotic spirit and again the questions needs to be asked whether they paid attention to the themes which did not fit in with their reasons for joining. Believing that patriotic themes were successfully transmitted is even harder to accept when you consider that some joined, as Summers (1976, p. 107) notes, as they believed their weekly drill "served an anti-authoritarian or at least anti-aristocratic cause".

Similarly, the increase in school and public ritual like the celebration of Empire Day, the lauding of the monarch, military parades, and waving the flag which was intended to further promote feelings of patriotism and empire inclusion may have had little effect on the majority of youth. Enthusiasm for an activity does not necessarily imply that the message has been assimilated. As Porter (1984, p. 210) argues, "children could enthuse over the trappings of such events without being deeply persuaded".

It is important to remember that youth, especially working class youth, were not a ' tabula rasa' where ideas could simply be imprinted by what Porter (1984, p. 225) has termed "bourgeois propagandists". Ideas of patriotism and imperialism would take hold where the ground was most fertile, in the minds of of those who already had a connection with the empire, the families of those already involved in it. For the vast majority of young people, ideas of patriotism and empire were not easy to disseminate (Porter, 2004, p. 262) as they had a culture of their own, a culture which had until the later part of the nineteenth century been excluded from it, and where people had different concerns and needs and their own sense of belonging.

It is possible to argue, as Price (1977, p. 97) does, that 'the appeal of patriotic consensus never appealed much to the working classes," as it would be expected that the success of these schools and youth-groups to be trumpeted by contemporary commentators, yet the perception of imperialists at the time was pessimistic and the very fact that multiple media had to be engaged and for such a long period of time, does not indicate overwhelming success. Moreover, it was a frequent concern (Porter, 1984, p. 172) that the working classes were "temperamentally, almost proudly, unpatriotic".

It is hard to judge the effects of how effective the increased patriotic and imperialistic emphasis had on society. Some memoirs of the time certainly reflect the positive effect of this propaganda, yet the small number of working class memoirs available makes it difficult to make a judgment for society overall. Perhaps the best way to judge the effects, until further evidence is uncovered, is that whilst propagandist imperial bodies ' succeeded in diffusing their patriotic intentions' it was only to the point of raising awareness of the empire. As Porter (1984) comments that "in fact Britain was no more imperialistic in effect in 1900 that she had been in, say, 1850; the only difference as that now she was more open about it" (Porter, 1984, p. 196).

Through placing greater emphasis on patriotism and imperialism in schools and youth groups it was possible to raise awareness, if not the patriotism of the middle and upper classes. It may be too strong to argue that patriotism was largely irrelevant to the working classes, merely that it had tough competition from a strong and defined culture. If we return to the quotation from the beginning of the essay, if increased propaganda did not create the unity intended, perhaps it helped to continue and strengthen the loose coalition of classes in society, perhaps the ideas of order and service were to some extent communicated effectively into the national consciousness. 


\section{REFERENCES}

Blanch, M. (1979) 'Imperialism, nationalism and organised youth', in Clarke, J. et al (eds) Working Class Culture: Studies in History and Theory. Hutchinson Educational Press.

Heathorn, S. (1995) ' Let us remember that we too, are English: Constructions of Citizenship and National Identity in English Elementary School Reading Books, 1880-1914’, Victorian Studies, Spring 1995.

MacKenzie, J. (1984) Propaganda and Empire. Manchester: Manchester University Press.

Mangan, J.A. (1986) 'The grit of our forefathers: invented traditions, propaganda and imperialism' in MacKenzie, J. (ed) Imperialism and Popular Culture. Manchester: Manchester University Press.

Porter, B. (2004) The Absent-Minded Imperialists: Empire, Society and Culture in Britain. Oxford: Oxford University Press.

Porter, B. (2004) 'Empire, what Empire? Or why 80 \% of Early-and Mid-Victorians were Deliberately Kept in Ignorance of It', Victorian Studies, Winter, 46 (2).

Price, R. (1977) 'Society, status and jingoism:the social roots of lower middle class patriotism, 1870-1900; in Cossick, G (ed), The lower Middle Class in Britain 1870 - 1914. London: Croom Helm.

Stedman-Jones, G. (1974) ' Working-class Culture and working-class politics in London 1870-1900: notes on the remaking of a working class', Journal of Social history, 7.

Summers, A. (1976) 'Militarism in Great Britain before the Great War,' History Workshop Journal, Autumn (2).

Yeandle, P. (2003) 'Empire, Englishness and Elementary School History Education, c. 1880-1914', International Journal of Historical Learning, Teaching and Research, [Online]. Available at: http://www.centres.ex.ac.uk/historyresource/ journal5/Yeandle.pdf\#cooliris (Accessed: 16 June 2012). 